\title{
Ethical concerns about negative epigenetic eugenics for the genetic makeup of the future generations
}

\section{Preocupaciones éticas basadas en la eugenesia epigenética negativa para la composición genética de las generaciones futuras}

\section{Cesar Koppe-Grisolia ${ }^{1,2 *}$}

${ }^{1}$ Department of Genetics and Morphology, Institute of Biological Sciences; ${ }^{2}$ Cathedra UNESCO of Bioethics. Universidade de Brasília, Brasilia, Brazil

\begin{abstract}
What is the real weight of the influence of socioenvironmental factors on the modulation of gene expression and on the control of our behavioral characteristics? These social pressures modify gene expression, being transmitted to offspring by means of epigenetic changes. The selfishness, avarice, violence, and nepotism were marked epigenetically in ancestral genes by psychosocial pressures. How can one then assign any value judgment to bad behaviors, if this is an innate, instinctive characteristic that was inherited by group selection? Changing the transgenerational transmission of those genes involved with bad social behavior, by changing their gene expression through biosocial pressures based on morality, ethics, and social justice, would we be carrying out a kind of negative epigenetic eugenics? We are talking about our ethical responsibility for genetic makeup of the next generations.
\end{abstract}

Key words: Social behavior. Epigenetic eugenics. Biosocial. Selfishness.

\section{Resumen}

¿Cuál es el peso real de la influencia de los factores socioambientales en la modulación de la expresión génica y en el control de nuestras características conductuales? Estas presiones sociales modifican la expresión génica, que se transmite a la descendencia mediante cambios epigenéticos. Los estándares de comportamiento antiéticos como el egoísmo, la avaricia, la violencia, el nepotismo y otros malos comportamientos sociales, estaban marcados epigenéticamente en genes ancestrales por presiones psicosociales. Cambiando la transmisión transgeneracional de aquellos genes implicados en el mal comportamiento social y su expresión genética por medio de presiones biosociales basadas en la moral, la ética y la justicia social, ¿estaríamos llevando a cabo una especie de eugenesia epigenética negativa? Estamos hablando de nuestra responsabilidad ética para la composición genética de las próximas generaciones.

Palabras clave: Comportamiento social. Eugenesia epigenética. Biosocial. Egoísmo.

Correspondence:

${ }^{*}$ Cesar Koppe-Grisolia

Date of reception: 29-04-2021

Date of acceptance: 05-05-2021

DOI: $10.24875 /$ BUP. 21000005
Available online: $13-12-2021$

BIOETHICS UPdate 2021;7(2):87-96 www.bioethicsupdate.com

2395-938X / @ 2021 Centros Culturales de México, A.C. Published by Permanyer. This is an open access article under the terms of the CC BY-NC-ND license (http://creativecommons.org/licenses/by-nc-nd/4.0/). 


\section{Introduction}

Studies with identical (monozygotic) twins, who share the same genetic material, have shown the weight of heredity in determining many human behavioral characteristics. A characteristic that occurs simultaneously in identical twins does not occur in both non-identical (dizygotic) twins, who share $50 \%$ of their genes, suggesting that genetic factors control it. There is a range of genetic behavioral characteristics that are mainly the same between monozygotic twins and different between dizygotic twins, such as alcoholism, autism, Alzheimer's disease, depression, schizophrenia, psychotic disturbances, and attention deficit disturbances. Science has also shown that physical characteristics such as obesity, high cholesterol, arterial hypertension, breast cancer, rheumatoid arthritis, Parkinson's disease, and aortic ischemia have a preponderant genetic component, given the degree of relatedness between identical twins. Phenotypic differences between monozygotic twins may be attributed to environmental factors, so random events may act on one sibling but not on the other. Monozygotic twins physically share the same genes, but these genes may have different patterns of expression in each sibling, if they undergo different environmental influences. It is well known that all our characteristics, be they physical or behavioral, are the result of interactions between our genes and environmental factors. This explains how some of the physical differences between identical twins arise overtime.

According to this line of thought, habits or the psychosocial environment can aggravate the symptoms of diseases that have a genetic predisposition. On the other hand, medicine today possesses instruments that diagnose and propose therapies for these diseases. Thus, given the complexity of modifying genes, we instead modify the social condition (the environment) and, for many of these diseases, there are quite successful therapeutic procedures available. The inherited genetic material link generations, so life experiences of ancestors can be genetically expressed in descendants. Since the time of our most remote ancestors, all our actions have sought our survival and the protection of our direct descendants. Care of family and relatives is not just a commitment established by society or religion. This behavior runs very deep, as an instinct that leads us to take certain attitudes that go beyond our mere reason. Therefore, there are always conflicts between selfish action that seeks to protect descendants who share genes and action that is for the common collective good. This conflict is well explained by Richard Dawkins in The Selfish Gene ${ }^{1}$, where the struggle for survival is directly related to the propagation of heredity for subsequent generations.

According to Jürgen Habermas ${ }^{2}$, politicians and public administrators, charged with defending the public interest, instead may end up seeking personal advantage and rewards for kin, to the detriment of taxpayers. The view that politicians are servants who work only for the public good is terribly naive. How could the instinct for one's own survival and that of one's descendants practiced by the political class not have a genetic component? Is behavior that aims to benefit relatives at the cost of the public purse not exactly the wish to preserve heredity? In this case, it is necessary to change genes by changing the social environment. As nepotism is associated with genetic selection for kinship groups, it is stronger than ethics and morality. Just as genetic diseases are treated by modifying the environment, here this evil is dealt with by employing tough legislation, constant monitoring and enforcement, and a code of ethics for public service. 
Prolonged and excessive power generates vices that blind administrators and, sooner or later, they succumb to group instincts. History is full of examples of dictators and totalitarian leaders who gave in to this instinct. How many episodes of ethnic cleansing have we experienced in the past 200 years? This means selection of classes, and from the viewpoint of the sociobiologist, this is the selection of those who, in theory, share genes, to the detriment of those who do not share these genes. This evil is combated with democracy, free elections that allow power to change hands, and a limit to reelection. In the avalanche of degrading episodes of nepotism and corruption in oligarchies in general, mainly within the class of politicians and public administrators, the ills are treated in a variety of spheres by creating strong ethics committees, which are independent and free from clientelism, with mainly external members.

However, as we still cannot physically change what is written in our genes due to ethical implications, we have to live with some of these ills inherited from our ancestors, who lived in a world where man struggled to master the planet. The instinct to survive and to affirm one's own species has selected selfish genes over millennia of the evolutionary process of group selection, because in the past these genes served their purpose. However, we cannot just sit back and accept this condition, supposing that if something is written in our genes in a deterministic way there is nothing to be done about it. This is reductionist thinking and, in the light of new knowledge about genetics, it is mistaken thinking. For many years, genetic research has shown that genes codify proteins, enzymes, and hormones that determine phenotypes, including behavioral ones, in a unidirectional way, following a line of command centered in genetic information. That is, from the genotype to the phenotype.

However, many studies have recently shown that there is also a process running in the opposite direction. That is, the environment exerts pressure on the functioning of genes, modifying their expression, and this is called epigenetics. It has already been demonstrated in humans that emotionally traumatic or highly stressful situations alter the methylation of nitrogenous DNA bases and consequently modify the expression of certain genes, even silencing them in some cases. In other words, different environmental factors can modify gene expression, which then alters phenotypes; that is, physical and behavioral characteristics (Fig. 1).

The frequency and speed at which environmental factors cause epigenetic modifications are much greater than those caused by mutations in the physical structure of DNA. Many substances have already been identified as causing epigenetic alterations, such as heavy metals, endocrine disruptors (such as bisphenol A - present in plastics), pesticides, and toxins. Epigenetic alterations caused by methylation in the nitrogenous bases and/or acetylation in the histone proteins of chromatin due to exposure to environmental factors are associated with different types of disorders in humans, including cancer, arterial hypertension, diabetes type 2, asthma, psychiatric disturbances such as bipolar disorder and schizophrenia, and Alzheimer's disease ${ }^{3}$.

\section{The relevance of epigenetic findings}

Surprisingly, these epigenetic alterations can be inherited. Methylation also takes place in the DNA of male or female gametes and appears in offspring, which is an effect known as intergenerational 


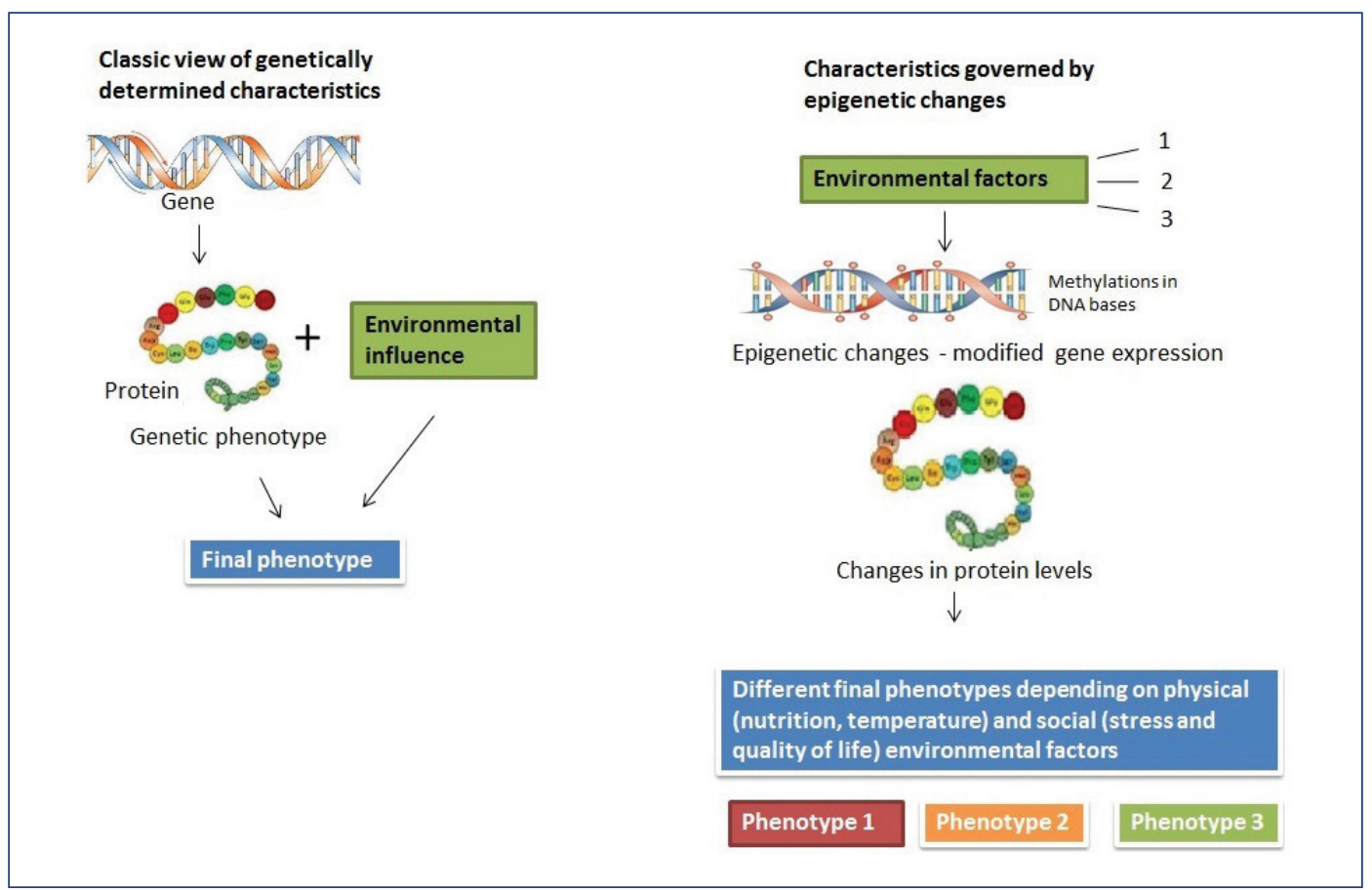

Figure 1. Showing the difference between a phenotype that arises by means of direct expression of a gene (on the left), and the more diverse types of phenotype that can arise when the same gene is under the control of different epigenetic factors (on the right).

transmission. Thus, epigenetic mutations are not accidental, as are the case with most structural mutations of DNA. The participation of environmental factors in epigenetic alterations causes different levels of genomic imprinting in gametes, revealing the biochemical history of the relationship an individual has with the surroundings ${ }^{3}$.

The evidence that disruption of the hypothalamus-pituitary-adrenal (HPA) axis is involved with behavioral disturbances in humans is becoming well substantiated. Increased glucocorticoid receptors (GR) and altered HPA axis have been found in humans after experiencing traumatic episodes. The polymorphism of the nr3c1 gene, which encodes the GR, is associated with emotional memory in healthy individuals. The hypermethylation of the $n r 3 c 1$ gene has been associated with depression and other psychological disorders, and this pattern of methylation is epigenetically controlled $d^{4,5}$.

Increased glucocorticoid sensitivity confers greater susceptibility to anxiety and depression. GR activation is correlated with coping appropriately with stress. A global pattern of methylations has been found in the NR3C1 gene of combat veterans with post-traumatic stress disorder (PTSD). Lower GR promoter methylation has been significantly associated with greater GR sensitivity, as indicated by greater post-dexamethasone cortisol suppression. An interesting finding in Holocaust survivors showed low cortisol and increased GR sensitivity in individuals with PTSD, caused by epigenetic alterations. Their children who were born after the Holocaust displayed psychiatric disturbances showing an intergenerational epigenetic effect ${ }^{6}$. 


\section{The example of maternal care}

In rodents, it has been demonstrated that maternal care of offspring promotes the release of neurotransmitters that act on the development of the hippocampus, which defines future social behavior in the adult. In contrast, the absence of maternal care generates deprivation, which influences the epigenome by means of DNA methylation, altering gene programming. This has neurological effects that may lead to behavioral disorders in the adult individual, such as anxiety and neophobia. The social environment in early life can provoke the reprogramming of genes, leading to future behavioral disorders ${ }^{7}$.

\section{The example of epigenetic alterations in child abuse}

There is evidence that a reduction in the expression of GR, due to methylation of the NR3C1 gene in the hippocampus, generates various psychopathological conditions, including mood changes, schizophrenia, and suicide. Sexual abuse in infancy is one of the strongest emotional traumas in existence. Studies with samples from the brain of adolescents who have committed suicide after experiencing sexual abuse in infancy have shown that the genes responsible for the synthesis of GR in the hippocampus had been methylated, which means their expression was repressed. The expression of these receptors decreased, leading to psychiatric disorders. In the control group, that is, adolescents who committed suicide but did not experience sexual abuse, the expression of these genes and the production of receptors were normal ${ }^{8}$.

\section{The example of the fungicide vinclozolin}

The fungicide vinclozolin was widely used in the cultivation of fruit and vegetables before it was banned worldwide. Male and female rats were exposed to vinclozolin and mated with partners that had not been exposed. Their descendants were analyzed for several generations. Descendants up to the third generation (F0 - exposed; F1, F2, and F3 - not exposed) presented a behavioral syndrome of anxiety, despite never having been exposed to the fungicide. In addition, the descendants up to the fourth generation presented a high incidence of prostate, testicular, and renal cancer. This example confirms the transgenerational effects of epigenetic alterations caused by environmental factors. Parents exposed to the pesticide underwent alterations in the methylation of gamete DNA, and these were transferred to future generations ${ }^{9}$.

\section{The influence of environmental factors on alterations in behavioral patterns with transgenerational effects, from an evolutionary perspective}

Epigenetic alterations caused by different patterns of gene expression modify phenotypes, which then undergo natural selection. These patterns of epigenetic alterations, known as genome imprinting, remain in maternal or paternal reproductive cells for several generations, segregating through Mendelian inheritance ${ }^{10}$. Cultural values are molded in the genes, by means of specific DNA methylation patterns, forming biocultural adaptations ${ }^{11}$. Considering macroevolutionary mechanisms that occur in populations that are under the influence or pressure of the same epigenetic factors, 
new behavioral patterns can arise and be segregated in descendants ${ }^{11}$. Thus, the presence of an environment with strong biosocial pressure can influence DNA methylation patterns, expressing behavioral phenotypes that are then subject to natural selection, as shown in the sequence of steps in figure 2. Evolution can take place in the epigenetic dimension more quickly than by natural selection through gene mutations. Those genes that have assimilated an epigenetic mark by means of environmental pressure also undergo adaptive processes and manifest their new phenotype in subsequent generations, named as rapid evolution ${ }^{12}$.

\section{Social dominance affirmed by means of DNA methylation patterns}

When fish of the species Astatotilapia burtoni show a high level of DNA methylation, they present dominant social behavior, with more aggression and a higher reproductive performance. When fish are exposed to a DNA demethylating agent (zebularine), they lose social characteristics of dominance and aggression and show passive behavior ${ }^{13}$. In honey bees (Apis mellifera), the levels of DNA methylation are associated with their social hierarchy in the colony. Castes determination in workers and queens is a process involving specific gene activations ${ }^{14}$. In other animal species, learning and memory patterns are also related to the levels of DNA methylation ${ }^{13}$. In this context, one can also consider the political dimension, where a hierarchical group maintains its dominance over a population for several generations. The environment can form the colonizers and the colonized, by means of genetically transmitted behavioral characteristics, which were molded in the distant past.

\section{Cultural heredity}

Jablonka and Lamb ${ }^{12}$ discussed systems of behavioral inheritance, especially in the dimension of epigenetics, and they define culture as socially transmitted behavioral patterns, "socially mediated learning is a change in behavior." In the process of genetic assimilation, acquired characteristics can influence the course of evolution, since they are incorporated in epigenetic inheritance. Phenotypes induced by behavioral patterns and then assimilated are transmitted transgenerationally, even if the inducing agent is not present in future generations; after adaptation, it persists. Various authors have used experimental models that demonstrate that acquired characteristics can be turned into hereditary characteristics. These characteristics can be both physiological and behavioral. These authors have been dubbed neo-Lamarckian.

This would be a new method of genetic manipulation, because unlike classical genetic engineering, which transfers a molecule of DNA (a gene) from one organism to another, instead, it is the pressure of behavioral patterns, producing epigenetic marks, which determine the appearance of new behavioral phenotypes with hereditary properties ${ }^{12}$.

This is a new ethical dilemma for humanity, if it establishes which behavioral gene patterns may contribute to a future society, and at the same time filters out genes that should be prevented from segregating in descendants, based on principles that safeguard the species on the planet. In contemporary society, many countries adopt the death penalty for murderers and chemical castration for rapists: are they not already establishing genetic filters of this kind? Could we say this is 


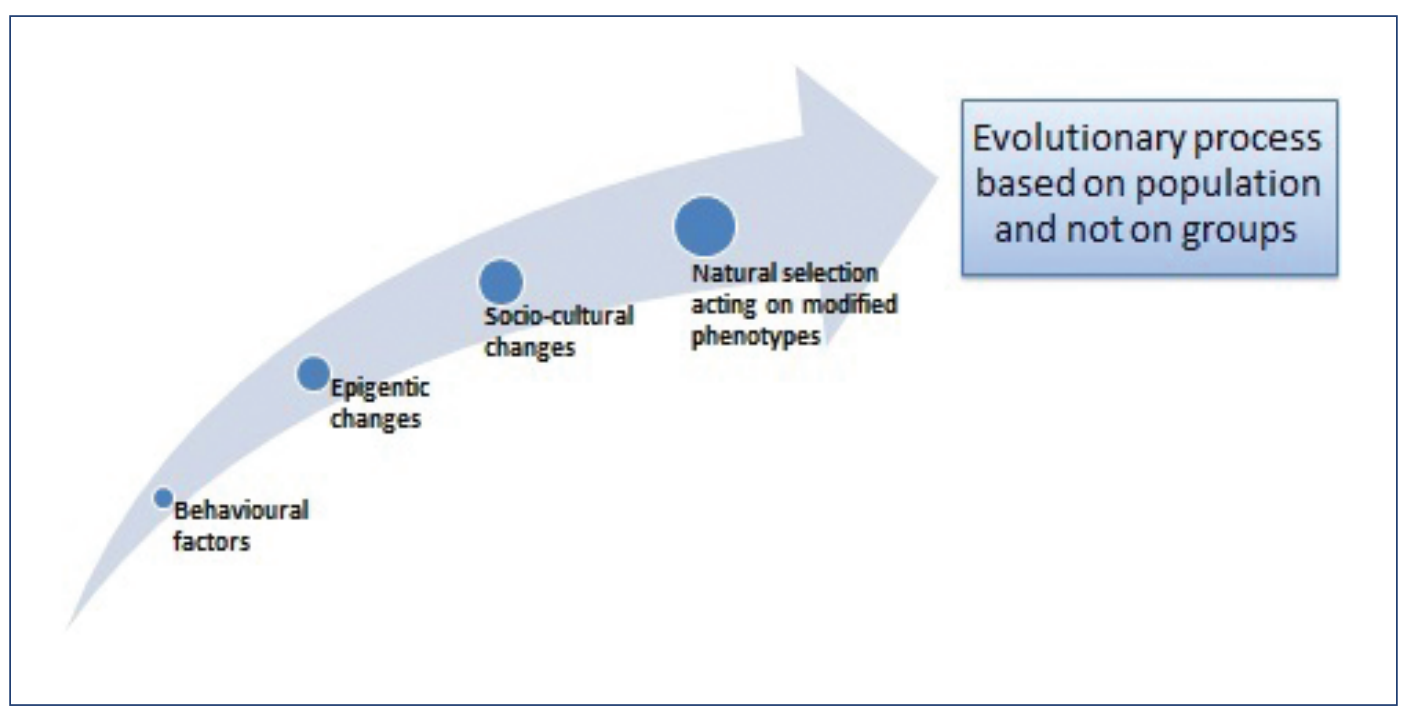

Figure 2. Inference of evolutionary mechanisms, changing the genetic profile of the population regarding selection of groups for collective behaviors.

epigenetic eugenics, and would this be ethically acceptable? What kind of ethics does a society have if it transmits to future generations those behavioral and cultural patterns that will compromise their future existence? And thus, we may be returning to the old and recurring topic of eugenics, now provided by a new and more efficient mechanism, epigenetic inheritance.

\section{Epigenetics, ethics, and responsibility - global actions}

Given that today's human population is planetary, global approaches will be necessary for all populations, based on the following premises: 1. the determination of global development policies that promote social well-being and the elimination of social inequalities and injustices; 2 . the peaceful and legal management of ethnic and racial conflicts; 3. collective actions taken in favor of a healthy environment, free of toxins, and pollution that cause stress and provoke biosocial degradations; 4 . bioethics in the use of genetic analyses of individuals or indeed populations that are faced with environmental epigenetic vulnerability.

These policies should then be under the responsibility of supranational organizations, such as the World Health Organization, UNESCO, and the UN. In an article dealing with transgenerational epigenetics, Meloni and Müller ${ }^{15}$ proposed that the social responsibility of transgenerational epigenetics must be an interdisciplinary approach, bringing together apparently contradictory disciplines to respond to the political challenge.

Our hypothesis is that behavioral factors of collective action favoring collective behavioral genotypes will prevail, by selection pressure, over behavioral genetic patterns that select groups. But what will these factors be? Are they already identified and in action? Changing the social environment through biosocial movements against genetic behaviors based on selfishness, avarice, nepotism, and 
other bad social behavior based on group selection, and on the other hand, benefiting collective altruistic behaviors seem to be ethically defensible. The epigenetic negative eugenics in this case is not a type of genetic improvement, and there would be no moral principle to condemn.

Nowadays, the human species is cosmopolitan and dominant, and it no longer runs the risk of extinction. Indeed, the risks that we might face are those that arise from our own selfish group selection behavior, such as disputes for power over natural resources that are of great economic value, geopolitical domain, or fundamentalism and ethnic cleansing. My theory is that in the evolutionary process, different types of genes were selected, based on group selection, such as selfishness, avarice, nepotism, violence, and other bad social behavior. At present, these genes represent a heritage from anthropoid primates, who struggled for survival on a hostile planet, and which we have not yet managed to undo or modify. Hence, they would be out of their evolutionary time. Other genes lead us to behave altruistically, that is, to practice actions that indiscriminately benefit those who are similar to us, even if they are not kin, so that we can have a society with greater equality among the people who are going to predominate in a future society, given that the species' preservation instinct has changed its focus. For now, the survival of humanity on the planet demands collective awareness and a new behavioral condition, and these relationships among people should be set above the relationships of groups or kin. In other words, social values based on morality and ethics that favor the collective will be more important than group selection's behavioral patterns, such as avarice, nepotism, violence, and selfishness. We will have to strengthen the command of the environment (society) over the gene. We still do not know how many generations will be necessary for this to happen.

\section{Are there any proposals on how to modify this condition?}

Yes. Global action to alleviate social tensions, ethnic conflicts, religious fundamentalism, exploitation of vulnerable populations, with sustainable social development projects and sustainable exploitation of natural resources. A proposed global action program led by supranational institutions. Multidisciplinary and continuous action programs for the long term. The Education 2030 Program, headed by UNESCO and UNICEF, with the participation of UN Women, the UNDP, the UNPF, the UNHCR, and the World Bank, arising out of the meeting in South Korea in May 2015, in the city of Incheon, which resulted in the drafting of a proposal known as the Declaration of Incheon, or "Education 2030: Incheon Declaration and Framework for Action: toward inclusive and equitable quality education and lifelong learning for all." Thus, the key agent of this transformation will be education ${ }^{16}$.

A new vision for education:

....to transform lives through education, recognizing the important role of education as a main driver of development and in achieving the other proposed SDGs. We commit with a sense of urgency to a single, renewed education agenda that is holistic, ambitious and aspirational, leaving no one behind.

....This Incheon Declaration is an historic commitment by all of us to transform lives through a new vision for education, with bold and innovative actions, to reach our ambitious goal by 2030.

Education has long been proposed as an instrument of social transformation, especially by the educator Paulo Freire in Brazil. It is a widely held dream to achieve a world without the conflicts 
and social injustices that we see in our world today. The educational formation of an individual gives her more opportunities to reach better professional conditions and the awareness needed for a more healthy life. And during this process the individual can have a more ethical attitude within society, in relation to other humans, to animals, and to the environment in general. In this case, we can consider that selection pressure may relax on those genes related to selfishness, nepotism, avarice, violence, and other bad group selection behaviors.

\section{Final remarks}

Analyzing this question only from the epigenetics dimension, we can confirm that in this process, genes are passive agents, since the chemical, physical, and social environment produce epigenetic marks in them, molding expression patterns. These patterns become hereditary and are incorporated in descendants.

Selfishness, avarice, violence, nepotism, and many other bad character and personality disorders represent now an evolutionary trash responsible for many anti-ethical behaviors, which were molded in the survival instincts of remote ancestors, based on Darwinian natural selection. As a basic principle, ethics is the behavioral posture of an individual acting in accordance with the laws and morality established by a society. How can one judge a rupture from the established moral and social-behavioral standard, if the biosocial values have been inherited? How can one blame the genes, if the genes themselves were molded by socioenvironmental pressures? Changing the transgenerational transmission of those genes involved with bad social behavior, by changing their expression to downregulation through biosocial pressures, would we carrying out a kind of negative epigenetic eugenics?

As discussed above, we have the tools to change gene expression using chemicals as well as environmental pressures. Research is going very fast in this field, being easily possible to undertake gene-driven epigenetics, using CRISPR technology to change the methylation pattern of a determined gene promoter ${ }^{17}$. Thus, by modifying the expression of the hereditary trash of selfishness and other bad social behavior with repercussions on future generations, we would be carrying out a kind of negative epigenetic eugenics. After all, the fact that an individual is not to blame for her inherited genes means she is not in an anti-ethical condition. How does bioethics deal with this dilemma? While these types of genes continue to express themselves in individuals, society will go on living with these hereditary evil.

Eugenics carried out to improve one genetic characteristics in an individual is ethically condemned, the so-called positive eugenics. However, social pressures to avoid epigenetic mark of bad social characteristics, negative eugenics, which would be passed on to future generations could be equally condemned? Taking into account that the evolutionary process based on epigenetic changes would be faster than that based on gene mutations followed by natural selection, and that the epigenetic marks can be reversible, in theory, this could be a feasible mechanism. Raising awareness through education would be the turning point in this process. Hence, we are talking about our ethical responsibility for genetic makeup of the next generations so that we can have a society with less inequalities and more just. 


\section{Funding}

This research has not received any specific grant from agencies of the public, commercial, or non-profit sectors.

\section{Conflicts of interest}

The author declares that there are no conflicts of interest.

\section{Ethical disclosures}

Protection of human and animal subjects. The author declares that no experiments were performed on humans or animfor this study.

Confidentiality of data. The author declares that he has followed the protocols of his work center on the publication of patient data.

Right to privacy and informed consent. The author has obtained the written informed consent of the patients or subjects mentioned in the article.

\section{References}

1. Dawkins R. The Selfish Gene. London: Oxford University Press; 1976. p. 224.

2. Habermas J. The Future of Human Nature. United Kingdom: Polity Press; 2003. p. 136.

3. Dupras C, Ravitsky V, Williams-Jones B. Epigenetics and the environment. Bioethics. 2014;7:327-34.

4. Yehuda R. Status of glucocorticoid alterations in post-traumatic stress disorder. Ann N Y Acad Sci. 2009;1179:56-69.

5. Ackermann S, Heck A, Rasch B, Papassotiropoulos A, de Quervain DJ. The Bcll polymorphism of the glucocorticoid receptor gene is associated with emotional memory performance in healthy individuals. Psychoneuroendocrinology. 2013;38:1203-7.

6. Yehuda R, Lehrner A. Intergenerational transmission of trauma effects: putative role of epigenetic mechanisms. World Psychiatry. 2018;17:243-57.

7. Szyf M, Weaver I, Meaney M. Maternal care, the epigenome and phenotypic differences in behavior. Reprod Toxicol. 2007;24:9-19.

8. McGowan PO, Sasaki A, D'Alessio AC, Dymov S, Labonte B, Szyf M, et al. Epigenetic regulation of the glucocorticoid receptor in human brain associates with childhood abuse. Nat Neurosci. 2008;12:342-8.

9. Nilsson EE, Anway MD, Stanfield J, Skinner MK. Transgenerational epigenetic effects of the endocrine disruptor vinclozolin on pregnancies and female adult onset disease. Reproduction. 2008;135:713-21.

10. Turner BM. Environmental sensing by chromatin: an epigenetic contribution to evolutionary change. FEBS Lett. 2011;585:2032-40.

11. Giuliani C, Bacalini MG, Sazzini M, Pirazzini C, Franceschi C, Garagnani P, et al. The epigenetic side of human adaptation: hypotheses, evidences and theories. Ann Hum Biol. 2015;42:1-9.

12. Jablonka E, Lamb ME. Evolution in Four Dimensions-genetic, Epigenetic, Behavioral and Symbolic Variations in the History Life. United States: MIT Press; 2005. p. 511.

13. Lenkov K, Lee MH, Lenkov OD, Swafford A, Fernald RD. Epigenetic DNA methylation regulates social dominance. PLoS One. 2015;10:e0144750.

14. Evan JD, Wheeler DE. Differential gene expression between developing queens and workers in the honey bee, Apis mellifera. Proc Natl Acad Sci. 1999;96:5575-80.

15. Meloni M, Müller J. Transgenerational epigenetic inheritance and social responsibility: perspectives from the social sciences. Environ Epigenet 2018;4:dvy019.

16. UNESCO. Education 2030: Incheon Declaration and Framework for Action: towards Inclusive and Equitable Quality Education and Lifelong Learning for All; 2016. Available from: http://www.unesco.org. Last accessed on 2019 Jun 20.

17. McDonald JI, Celik H, Rois LE, Fishberger G, Fowler T, Rees R, et al. Reprogrammable CRISPR/Cas9-based system for inducing site specific DNA methylation. Biol Open. 2016;5:866-74. 